\title{
Integration of Webqual Method to Importance Performance Analysis and Kano Model to Analyze System Quality of E-Government: Case Study LAPOR!
}

\author{
Fiena Rindani* \\ Information System Software, \\ Management of Information System, \\ Gunadarma University \\ Depok, Depok, 16424, Indonesia \\ fien.rien@gmail.com
}

\author{
Sulistyo Puspitodjati \\ Information System Software, \\ Management of Information System, \\ Gunadarma University \\ Depok, Depok, 16424, Indonesia \\ sulistyo@ staff.gunadarma.ac.id
}

\begin{abstract}
The management of public complaints in many institutions in Indonesia has not been managed effectively and integrated. Each institution works partially and not coordinated well. This causes duplication of handling complaint, or worse is a complaint possibly not handled by any of institution, due to the reason that the complaint is not their authority. For

this reason, the Government of the Republic of Indonesia established a S4N-LAPOR!.

Meanwhile, there are still some deficiencies in LAPOR. This research purpose is to analyzelevaluate LAPOR using an integration of Webqual method to Importance Performance Analysis (IPA) and Kano model. This research is only carried out by analyzing web-based LAPOR services. The questionnaires are distributed to 159 respondents. The webqual method is used to determine the dimension and attributes, while the IPA and Kano model is conducted for data analysis. The integration from the results of both data analysis

shows that there are 14-attributes out of 23 that need to be the priority for LAPOR improvements.
\end{abstract}

Keyword: LAPOR, Webqual, IPA, Kano, e-government

\section{Introduction}

E-government is the use of information and communication technology in the process of governance to realize an effective, efficient, transparent, accountable and easily accessible to all parties (citizens, businesses, and others). E-government gives so much benefit, one of them is to enable community creation and gives citizens or businesses the possibility to participate and contribute actively in governmental discussion for the decision-making process (Joseph 2015). Generally, public service is always related with the performance and program in implementation of e-government. Public service has a central role in many aspects of human life, and as the functions in maintaining the existence and growth of the community, the nation and the state.

Indonesia is a Southeast Asian nation made up of thousands of volcanic islands. It is one of the biggest developing countries with over 257 million citizens. Therefore, providing balanced services is challenging for Indonesia. However, the fact that internet penetration has reached over $40 \%$ of the

*Corresponding Author 
total population and the rapid developments in Information and Communication Technologies (ICTs) in Indonesia have been giving an important role for providing balanced public services for all citizen through e-government. Through the e-government, the citizens can interact with the government anytime and anywhere without the necessity for physical travel to government offices and agents.

One of the e-government that has been provided by Indonesia's government is LAPOR. LAPOR is an online portal where public can directly report their problem concerning public services, send their complaint regarding public servant, and monitoring government's development program. However, LAPOR's performance has several limitations, such as LAPOR's publication has not been good enough in terms of people awareness about this platform. This lack of publication and people awareness also reflected from the number of users that are relatively not significant enough. Total users are only 891.257. This number contrasts with the total internet users which reached 171 million. The rating of LAPOR application on the Apple App Store is 2.9, and Play Store is 3.9 out of 5.0 scale and many users are still disappointed over the services and features provided by LAPOR.

This is really unfortunate that LAPOR has potential use for the citizen, as commonly the citizen does not know how and to whom their aspiration or complaint of the public sector report should be addressed due to the common one-way interaction for current complaint system. Therefore, this research aims to analyze the performance of e-government, in case study is LAPOR, in Indonesia. The evaluation will be using integration of Webqual Method to define the requirement needed, and Importance Performance Analysis and Kano model as the data analysis process to measure the satisfaction and find possible improvements.

\section{Literature Review}

\section{E-government}

The World Bank defines e-government as the use by government agencies of ICT like wide area network, the internet and mobile computing that have the ability to transform relations with citizens, businesses, and other arms of government (Al-Nidawi et al 2018). The main emphasis of egovernment is not the implementation of new ICT systems to automate the traditional public service processes or add a new online service delivery channel per se, but rather it aims at improving transparency, accountability, and governance of the public sector services and in so doing it can improve government performance and create new public value for citizens and businesses (Al-Hujran et al 2015).

The Indonesia's government had committed to spending US\$6.78 billion for e-government development from 2014 to 2019 (Sabani et al 2018). With the implementation of such an initiative, the e-government in Indonesia was supposed to be developed progressively. In fact, the United Nations (UN) published the EGDI (E-Government Development Index) ranking based on the 2018 survey, which Indonesia ranked 107th out of 193 UN member states, shown in Figure 1 (Widowati 2018). 


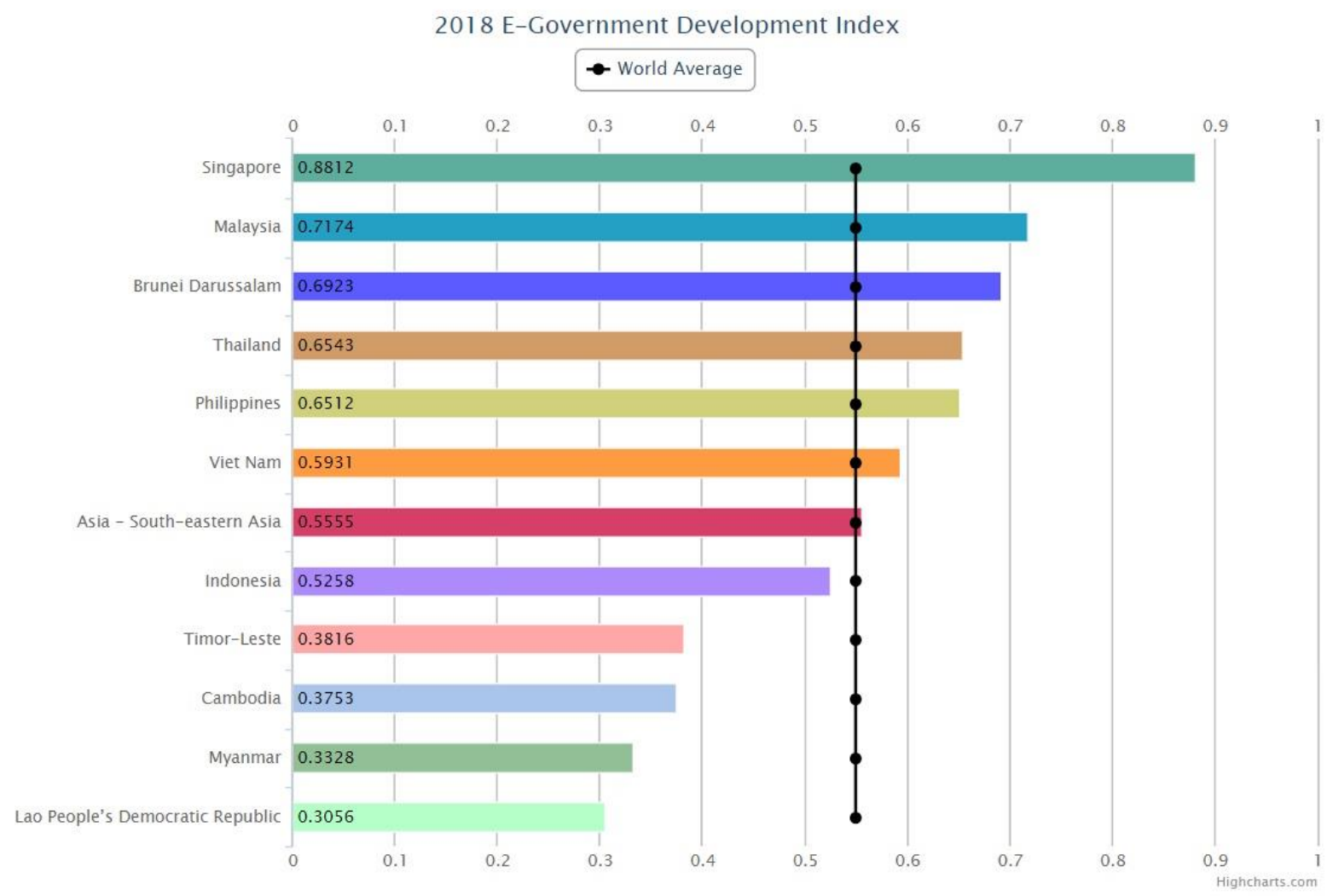

Figure 1. 2018 E-Government Development Index (Widowati 2018)

\section{LAPOR}

LAPOR! is a G2C e-government by Indonesian government which established as the public service complaint management system (Indonesian: Sistem Pengelolaan Pengaduan Pelayanan Publik Nasional - SP4N) based on 'Peraturan Presiden Nomor 76 Tahun 2013' and 'Peraturan Menteri Pendayagunaan Aparatur Negara dan Reformasi Birokrasi Nomor 3 Tahun 2015'. It is is first initiated in 2011 by UKP-PPP. SP4N-LAPOR! is now managed by Ministry of Administrative and Bureaucratic Reform (Indonesian: Kementerian Pendayagunaan Aparatur Negara dan Reformasi Birokrasi) as public service regulatory, Presidential Staff Office (Indonesian: Kantor Staf Presiden) as regulator of national priority program, and Ombudsman Republik Indonesia as regulator of public sevice (LAPOR 2020).

LAPOR!, shown in Figure 2, is an online portal where public can directly report their problem concerning public services, send their complaint regarding public servant, and monitoring government's development program. LAPOR! has been connected with 34 Ministries, 96 Institutions, and 493 Regional governments in Indonesia. The number of users by January 2019 is 801,257 and total reports that have been submitted are 1,389,891 (LAPOR 2020).

The public can send aspiration/report/complaint on LAPOR! through various media including the site www.lapor.go.id, SMS 1708, and mobile application. The report will be verified by the administrator for clarity and completeness then will be forwarded to the institution. LAPOR! will publish each report that has been forwarded to the relevant institution and giving the user continued notification. The authorized institution who handled the complaints is given maximum 5 working days for internal coordination and formulation for following-up the report. If the institution has met the final response, they will inform the reporter in follow-up page (LAPOR 2020). 


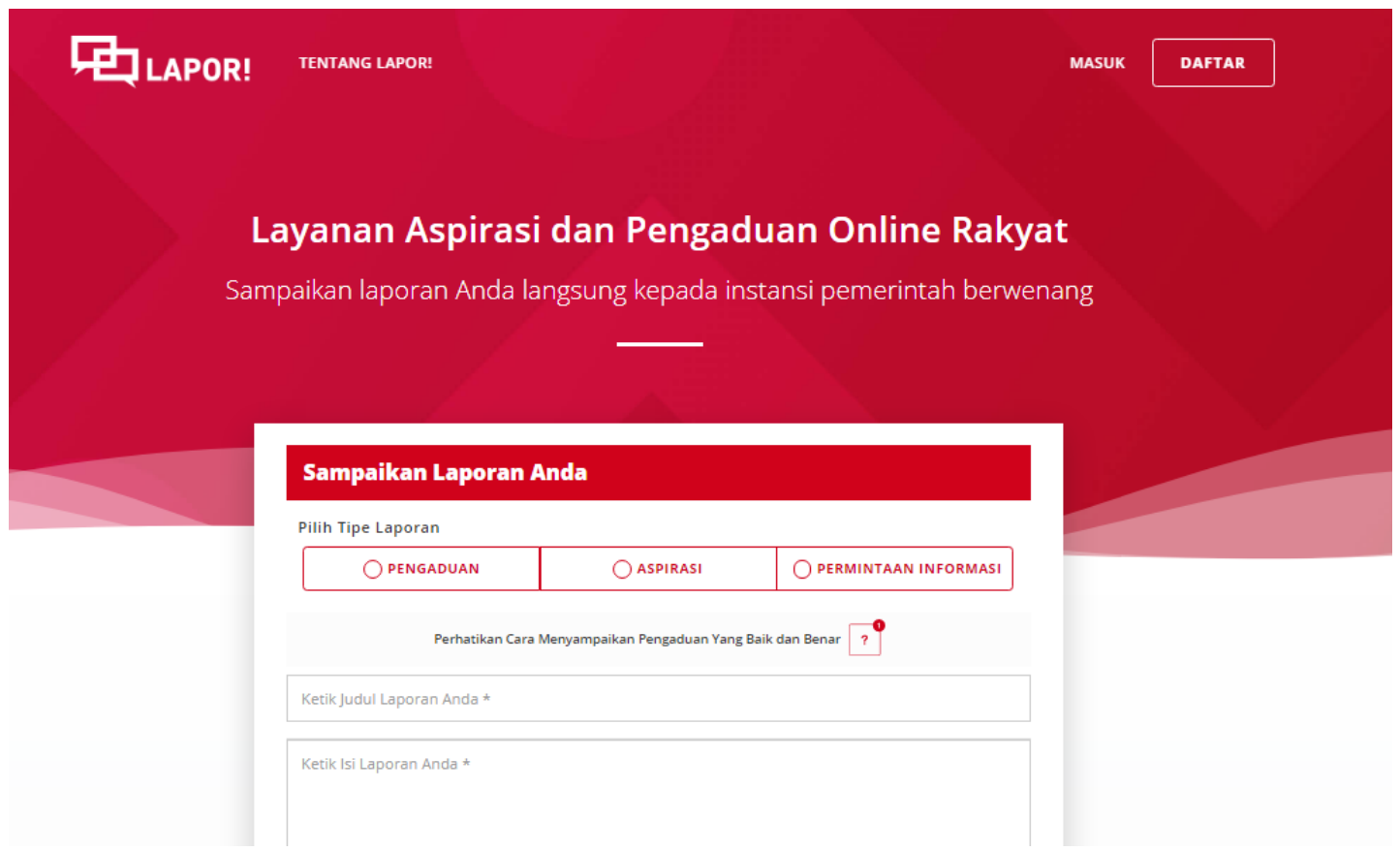

Figure 2. Lapor Home Page (LAPOR 2020)

\section{Webqual Method}

Webqual is an instrument for assessing user perceptions of the quality of websites based on end-user perception. This method is a development of SERVQUAL which was widely used before in measuring service quality. The webqual instrument has been under development since the early part of 1998 and has experienced several interactions in the preparation of dimensions and questions (Andry et al 2019). The method has evolved via a process of iterative refinement, starting from webqual 1.0 to webqual 4.0.

The following is an explanation of the three dimensions of webqual 4.0 (Arnes and Hanum 2019):

1. Usability Quality, namely the quality dimension related to site design and usability. This dimension includes appearance, interface, ease of use, ease of understanding, ease of navigation, and displays an attractive visual form.

2. Information Quality, which is the dimension of the content of information on the site (conformity of information with user objectives), such as the accuracy of the information, context, format, and its relevance.

3. Service Interaction, namely the dimensions of quality of service interactions experienced by users that are manifested by trust and empathy, for example, a sense of security during the transaction, information security, product delivery, personalization, and communication with site owners.

\section{Importance Performance Analysis (IPA)}

Importance-Performance Analysis (IPA) is a technique for analyzing customer satisfaction towards an organization's product or service as proposed by Martilla and James in 1977. IPA measures the satisfaction from customer satisfaction surveys based on two components of product or service attributes: the importance of a product or service to a customer and the performance of an organization in providing that product or service (Martilla and James 1977).

For a considerable period, IPA has been used as a tool for understanding customers' needs and desires to develop marketing strategies to respond to them. IPA is widely used in many areas in which customer satisfaction is a key to a thriving business including higher education, government service, tourism, convenience store and bank service (Phadermrod et al 2016). 
The IPA used a Cartesian model in which the mean for performance (perceptions) and importance (expectations) are plotted for each variable, shown in Figure 3. The IPA gives a better explanation of graphical view of the dimension the company should give more attention and priority since it presents as four quadrants I, II, III, IV (Padlee et al 2019):

1. The first quadrant, concentrate here, indicates low performance on attributes of high importance, thereby highlighting priority areas requiring immediate improvement.

2. The second quadrant, keep up the good work, represents high performance on attributes of high importance thereby indicating that the current quality should be maintained.

3. The third quadrant, low priority, represents low importance and low performance, suggesting that these attributes require only a limited amount of attention.

4. The fourth quadrant, possible overkill, represents high performance on attributes of low importance, thereby indicating an opportunity to redirect resources to areas of greater priority.

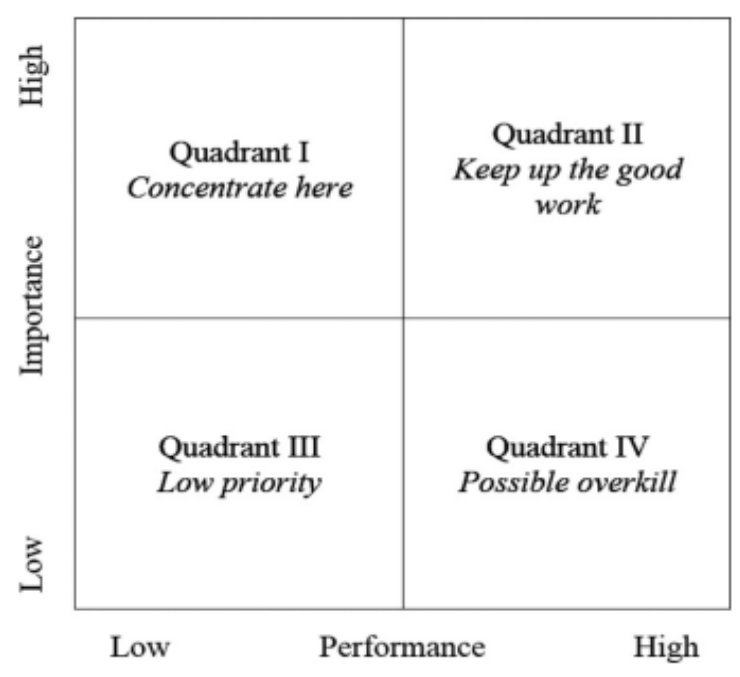

Figure 3. IPA Matrix (Padlee et al 2019)

\section{Kano Model}

Kano model was first proposed by Professor Noriaki Kano, an expert on quality management in Japan. Inspired by Herzberg's two-factor theory, Kano and his colleagues at the Tokyo Rika University in Japan presented Kano's theory of attractive quality to understand how customers' perceive and evaluate product or service quality (Materla et al 2019). The model believes that "satisfying" is not simply in opposition to "dissatisfying" and that product attribute fulfillment can influence customer satisfaction in a nonlinear way.

Consequently, the Kano model is used to analyze product attributes for customers' requirements mainly in six different situations (Dou et al 2016):

1. A: Attractive, customer satisfaction will not decrease even if requirements in this category are not fulfilled. However, fulfilling these requirements will drastically increase customer satisfaction.

2. O: One-dimensional, fulfilling requirements in this category increase customer satisfaction. Conversely, not fulfilling these requirements decreases customer satisfaction.

3. M: Must-be, customer satisfaction will not increase even if requirements in this category are fulfilled. However, not fulfilling these requirements drastically decreases customer satisfaction.

4. R: Reverse, fulfilling requirements in this category decreases customer satisfaction as customers have no such requirements.

5. I: Indifferent, customer satisfaction will not change regardless of whether requirements in this category are fulfilled.

6. Q: Questionable, requirements in this category should be ignored because there is a paradox when explaining them. 
To be able to categorize requirements or quality attributes into these groups, it is necessary to use the Kano questionnaire. It contains a pair of questions for each requirement. One question is worded positively to find out how the respondent would feel if the product met the specific requirement. The second question is worded negatively to shows how not fulfilling the requirement affects the (dis)satisfaction of the respondent. There are five options for the respondent, ranging from very satisfied to very dissatisfied (Madzík et al 2019). The particular types of requirements in this coordinate system have the form of curves, shown in Figure 4 (Shahin et al 2013).

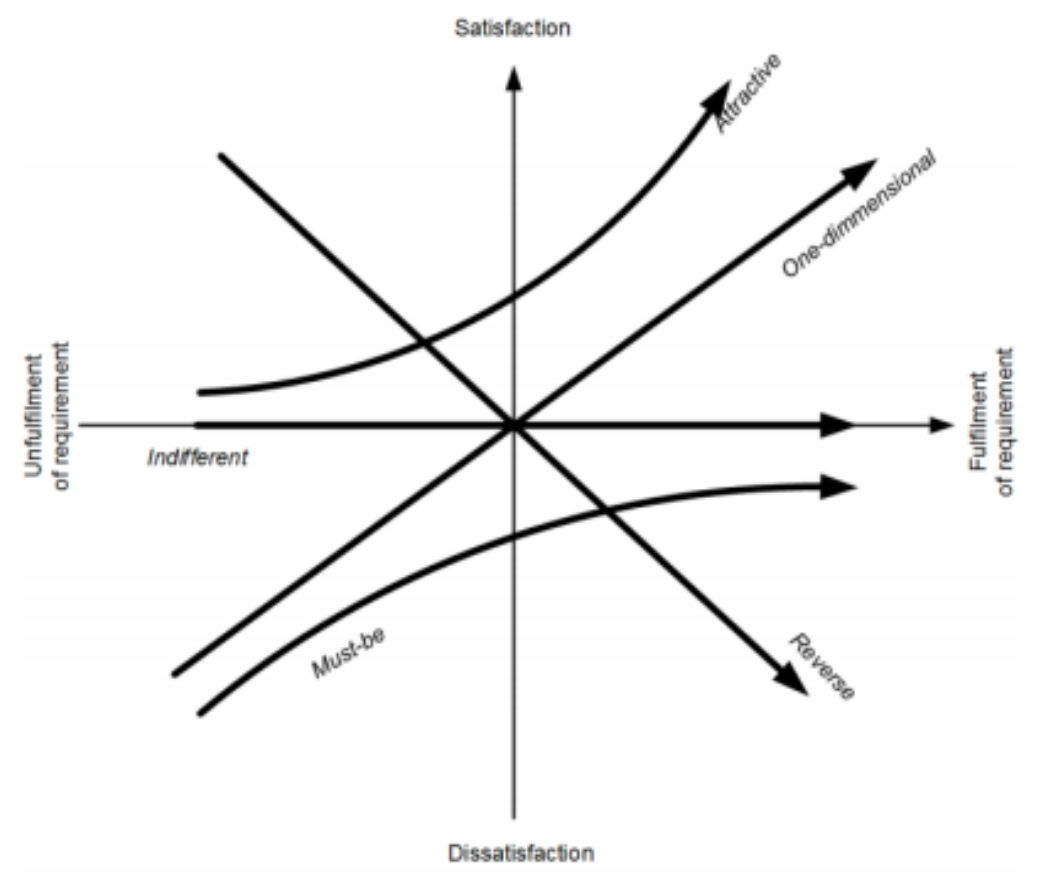

Figure 4. Kano Categories (Shahin et al 2013)

\section{Methodology}

\section{Research Design}

Figure 5 illustrates the flow design of this research. First, the problem statement and research objective are determined to find focus, purpose, and limitation of this research. Next, the sample as the participants of this research is determined. Then the next process is searching for the appropriate method as the researcher needed. After that the questionnaires are prepared, it divided into 2 types: (1) Webqual questionnaire, and (2) Kano questionnaires. Both questionnaires are distributed to the sample as the respondents. Then data is collected as the result of questionnaires. The result data then are analyzed by using by Importance Performance Analysis (IPA) and Kano model. After the data analysis process, the conclusion of the research is drawn. 


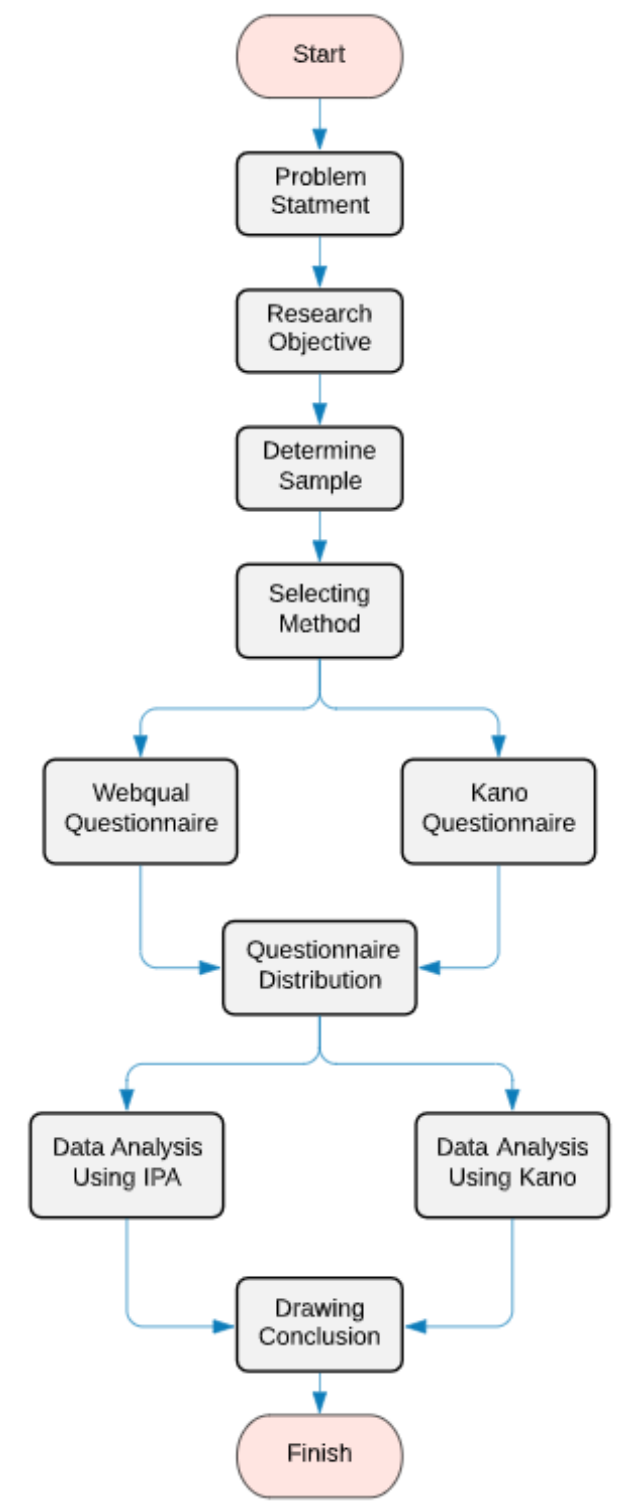

Figure 5. Research Design

\section{Population and Sample}

Population of this research is the number of users registered in LAPOR website (891.257 users in February 2020). While the sample is obtained using the Slovin equation (Equation 1):

$\mathrm{n}=\mathrm{N} /\left(1+\mathrm{N}(\mathrm{e})^{2}\right)$

Equation (1)

Where:

$$
\begin{aligned}
& \mathrm{n}=\text { sample } \\
& \mathrm{N}=\text { population } \\
& \mathrm{e}=\text { error sampling }
\end{aligned}
$$$$
\mathrm{n}=801.257 /(1+801.257)(0.1)^{2}=99.987 \text { respondents }
$$

From the above calculation shows that the number of respondents needed to fulfill the minimum number of criteria is 100 respondents, while this research conducted in 159 respondents. 


\section{Research Variable}

Variables used in this research as measurement instrument is Webqual 4.0 method. Table 1 shows the details of Webqual dimensions used in this research which are the item code, and attribute. It consists of 23 items used as instruments for Webqual and Kano's questionnaires. The Webqual method consists of dimensions as follows (Barnes and Vidgen 2002):

1. Usability is draws in the human computer interaction. It is concerned on how a user perceives and interacts with LAPOR, such as navigation, and ease of use, to accomplish goals in efficient and effective way.

2. Information Quality indicates quality of the content of a website. This dimension illustrates the quality of information that presented on LAPOR from users' perspective, as it should be accurate, up to date, and coherent.

3. Service Interaction indicates the quality of service and interaction experienced by users when they use website for more important transaction. It also has a strong relation to trust, and empathy. For LAPOR this dimension relates to how LAPOR handle the complaints, and security of the information.

4. Overall View is an additional dimension, to ask the user perceived of the overall view of the website.

Table 1. Research Variable

\begin{tabular}{|c|c|c|}
\hline Dimension & Item code & Attribute \\
\hline \multirow[t]{8}{*}{ Usability } & U1 & Easy to learn to operate \\
\hline & $\mathrm{U} 2$ & Interaction is clear and understandable \\
\hline & U3 & The site easy to navigate \\
\hline & $\mathrm{U} 4$ & The site easy to use \\
\hline & U5 & Attractive appearance \\
\hline & U6 & Appropriate to the type of site \\
\hline & U7 & Conveys a sense of competency \\
\hline & U8 & Creates Positive experience \\
\hline \multirow{7}{*}{$\begin{array}{l}\text { Information } \\
\text { Quality }\end{array}$} & IQ1 & Provides accurate information \\
\hline & IQ2 & Provides believable information \\
\hline & IQ3 & Provides timely information \\
\hline & IQ4 & Provides relevant information \\
\hline & IQ5 & Easy to understand information \\
\hline & IQ6 & Information at the right level of detail \\
\hline & IQ7 & Information in appropriate format \\
\hline \multirow{7}{*}{$\begin{array}{l}\text { Service } \\
\text { Interaction }\end{array}$} & SI1 & Good reputation \\
\hline & SI2 & Safe to complete transactions \\
\hline & SI3 & Personal Information feels secure \\
\hline & SI4 & Sense of personalization \\
\hline & SI5 & Sense of community \\
\hline & SI6 & $\begin{array}{l}\text { Communicate with the organization who handle the } \\
\text { complaint }\end{array}$ \\
\hline & SI7 & Confident that the complaint will be delivered as promised \\
\hline Overall view & $\mathrm{O} 1$ & Overall view of the website \\
\hline
\end{tabular}




\section{Scale}

The scales used in this research are:

1. Webqual questionnaire

- Importance to measure the quality that user desired, for example: "I feel that LAPOR is easy to learn to operate", the answer options use Likert Scale of 1 to 5 as follows: $1=$ Very not Important; 2 = Not Important; 3 = Neutral; 4 = Important; 5 = Very Important.

- Performance to measure perceived of the current quality from user perceived, for example: "How important that LAPOR is easy to learn to operate?", the answer options use Likert Scale of 1 to 5 as follows: $1=$ Strongly Disagree; $2=$ Disagree; $3=$ Neutral; $4=$ Agree; $5=$ Strongly Agree.

2. Kano questionnaire

- Functional to determine the feeling perceived by user to have a feature, for example: "How do you feel if LAPOR is easy to learn to operate?"

- Dysfunctional to determine the feeling perceived by user not to have a feature for example: "How do you feel if LAPOR isn't easy to learn to operate?"

The answer options for both of the questions use Likert Scale of 1 to 5 as follows: $1=\mathrm{I}$ like it that way; 2 = It must be that way; 3 = I am neutral; 4 = I can live with that way; $5=$ I dislike it that way.

\section{Results}

\section{Demographic Characteristic of the Sample}

All the respondents of this research are LAPOR users which have been questioned in questionnaire as the criteria of respondent. Characteristics of respondents are shown in Figure 6. Regarding the gender, $53 \%$ equals to 84 participants are female, and $47 \%$ equals to 75 participants are male. Based on age group, there is none participant less than 18 years old; 18 to 25 years old is 56 participants (35\%), 26 to 35 years old is 49 participants $(31 \%)$, and more than 35 years old is 54 participants $(34 \%)$. Regarding the occupation, 17 are students (11\%), 70 are civil servants (44\%), 35 are private employees (22\%), 3 are entrepreneur (2\%), and others is 34 participants (21\%). Based on last education, senior high school is 24 participants (14\%), diploma is 13 participants (8\%), bachelor degree is 75 participants (48\%), master degree is 45 participants $(29 \%)$, and doctoral degree is 2 participants (1\%).

\section{Test Instrument}

Test instrument is conducted by Reliability test and validity test. The tests are done to the result of data collected from both Webqual (performance and importance) and Kano (functional and dysfunctional) questionnaire in 23 attributes. It is conducted by using program application namely SPSS as the tools.

1. Reliability Test

Reliability refers to the consistency of a measure. Cronbach Alpha is used to measure the reliability of the data. Table 2 shows that the Cronbach alpha score for all the data in 23attributes is greater than 0.60 , therefore the data is reliable.

Table 2. Reliability Test Result

\begin{tabular}{|r|r|r|r|r|l|}
\hline \multicolumn{2}{|l|}{ Webqual Cronbach's Alpha } & \multicolumn{2}{l|}{ Kano Cronbach's Alpha } & \multirow{2}{*}{ No. of Items } & \multirow{2}{*}{ Description } \\
\cline { 1 - 4 } Performance & Importance & Functional & Dysfunctional & & \\
\hline $\mathbf{0 . 9 7 2}$ & 0.960 & 0.964 & 0.975 & 23 & Reliable \\
\hline
\end{tabular}




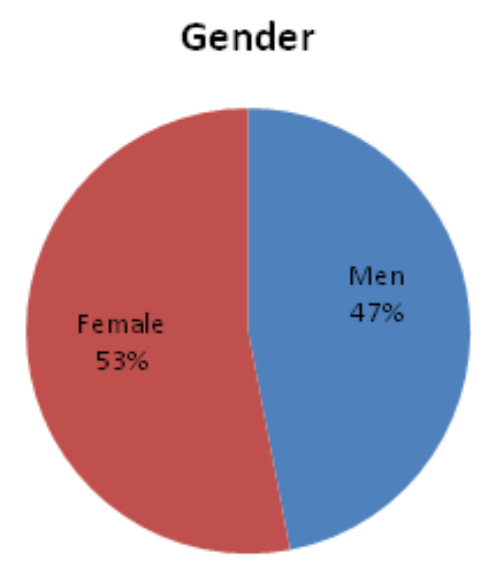

Occupation

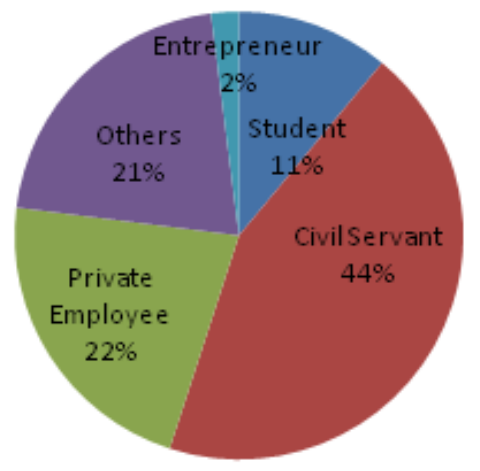

Age Group

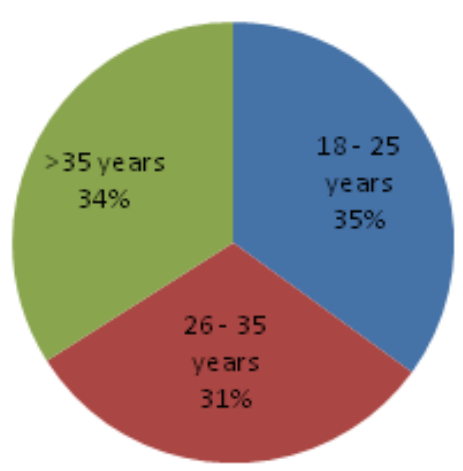

Last Education

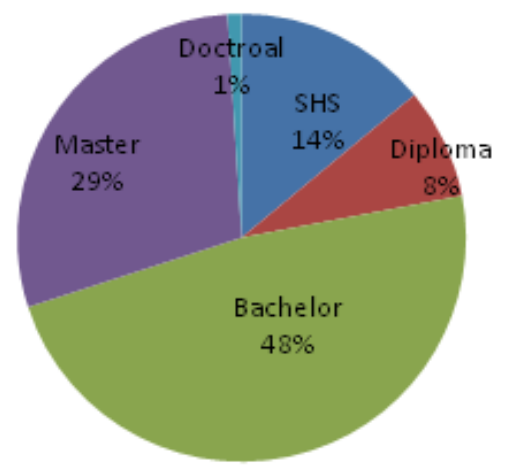

Figure 6. Demographic of Sample

2. Validity Test

Validity is often defined as the extent to which an instrument measures what it asserts to measure. Corrected coefficients by Pearson is used to determine wheatear the data is valid or not. Table 3 shows that the validity score for all data in 23-attributes are in between 0.6 to 0.8 . From the $\mathrm{r}$ Table for $\mathrm{df}=(\mathrm{N}-2)=157$, and sig ( 2 tailed) $0.01=1 \%$ is 0.2037 . It can say that all of the data are valid, $r>0.2037$.

\section{Data Analysis for Webqual and IPA}

After data collection process throughout the questionnaire using Webqual method, the following process is data analysis using importance performance analysis. It consists of analysis of GAP and analysis of quadrant IPA.

1. GAP Analysis

Table 4 shows the results of GAP score. GAP analysis is conducted to see the difference of performance and importance score using Equation 2.

$$
\mathrm{Qi}(\mathrm{GAP})=\operatorname{perf}(\mathrm{i})-\operatorname{imp}(\mathrm{i})
$$

Where:

$$
\begin{aligned}
& \text { Qi }(\text { GAP })=\text { GAP score } \\
& \operatorname{perf}(\mathrm{i})=\text { Performance mean } \\
& \operatorname{imp}(\mathrm{i})=\text { Importance mean }
\end{aligned}
$$


Table 3. Validity Test Result

\begin{tabular}{|l|r|r|r|r|l|l|}
\hline \multirow{2}{*}{$\begin{array}{l}\text { Item } \\
\text { Code }\end{array}$} & \multicolumn{2}{|c|}{ Webqual Rcount } & \multicolumn{2}{|c|}{ Kano Rcount } & \multirow{2}{*}{ R-table } & Description \\
\cline { 2 - 5 } & Performance & Importance & Functional & Dysfunctional & & \\
\hline U1 & 0.676 & 0.606 & 0.615 & 0.731 & 0.2037 & Valid \\
\hline U2 & 0.758 & 0.655 & 0.648 & 0.811 & 0.2037 & Valid \\
\hline U3 & 0.795 & 0.599 & 0.661 & 0.800 & 0.2037 & Valid \\
\hline U4 & 0.817 & 0.601 & 0.688 & 0.811 & 0.2037 & Valid \\
\hline U5 & 0.758 & 0.745 & 0.790 & 0.832 & 0.2037 & Valid \\
\hline U6 & 0.781 & 0.69 & 0.721 & 0.777 & 0.2037 & Valid \\
\hline U7 & 0.784 & 0.736 & 0.766 & 0.851 & 0.2037 & Valid \\
\hline U8 & 0.779 & 0.704 & 0.759 & 0.658 & 0.2037 & Valid \\
\hline IQ1 & 0.782 & 0.750 & 0.811 & 0.745 & 0.2037 & Valid \\
\hline IQ2 & 0.780 & 0.813 & 0.797 & 0.769 & 0.2037 & Valid \\
\hline IQ3 & 0.804 & 0.822 & 0.795 & 0.825 & 0.2037 & Valid \\
\hline IQ4 & 0.803 & 0.792 & 0.811 & 0.902 & 0.2037 & Valid \\
\hline IQ5 & 0.826 & 0.730 & 0.776 & 0.902 & 0.2037 & Valid \\
\hline IQ6 & 0.842 & 0.829 & 0.765 & 0.747 & 0.2037 & Valid \\
\hline IQ7 & 0.848 & 0.798 & 0.783 & 0.829 & 0.2037 & Valid \\
\hline SI1 & 0.745 & 0.770 & 0.782 & 0.804 & 0.2037 & Valid \\
\hline SI2 & 0.830 & 0.749 & 0.766 & 0.883 & 0.2037 & Valid \\
\hline SI3 & 0.796 & 0.738 & 0.750 & 0.870 & 0.2037 & Valid \\
\hline SI4 & 0.789 & 0.790 & 0.762 & 0.832 & 0.2037 & Valid \\
\hline SI5 & 0.737 & 0.691 & 0.715 & 0.808 & 0.2037 & Valid \\
\hline SI6 & 0.803 & 0.749 & 0.766 & 0.808 & 0.2037 & Valid \\
\hline SI7 & 0.776 & 0.691 & 0.713 & 0.767 & 0.2037 & Valid \\
\hline O1 & 0.789 & 0.741 & 0.786 & 0.684 & 0.2037 & Valid \\
\hline
\end{tabular}

2. Quadrant IPA Analysis

Mean score of performance and importance in Table 4 is used to determine the position of each attribute on the Cartesian diagram. Figure 7 is the result of Cartesian graph. The diagram is divided into 4 quadrants, the $\mathrm{X}$ axis is performance and $\mathrm{Y}$ axis is importance for both of mean score for all attributes.

The following is the placement of each attributes of the dimensions in the Importance Performance Matrix (Cartesian diagram):

- Quadrant 1

Atrributes that included in quadrant I (Concentrate Here) is considered as important but has low performance. This quadran defines which attributes needs to be the priority for improvement in LAPOR, which are the site easy to navigate (U3), attractive appearance (U5), good reputation (SI1), and personal information feels secure (SI3).

- Quadrant II

Atrributes that included in quadrant II (Keep up The Good Work) is considered as important and has good performance. This quadran defines which attributes that has meet respondents expecation in LAPOR so that this attributes only need to keep up the good work of the quality, which are easy to learn to operate (U1), interaction is clear and 
understandable (U2), the site easy to use (U4), creates positive experience (U8), provides accurate information (IQ1), easy to understand information (IQ5), and overall view of the web site $(\mathrm{O} 1)$.

- Quadrant III

Attributes that included in quadrant III (Low Priority) is considered to has low importance and low performance. This quadran difenes which attributes in LAPOR that doesn't need much attention as the respondents has less expectation to this attributes, which are appropriate to the type of site (U6), provides timely information (IQ3), information at the right level of detail (IQ6), information in appropriate format (IQ7), sense of personalization (SI4), sense of community (SI5), communicate with the organization who handle the complaint (SI6), and confident that the complaint will be delivered as promised (SI7).

- Quadrant IV

Attributes that included in quadrant IV (Possible Overkill) is considered to has low importance but good performance. This quadran difenes which attributes that is not very important but has good performance in LAPOR, which are conveys a sense of competency (U7), provides believable information (IQ2), provides relevant information (IQ4), and safe to complete transactions (SI2).

Table 4. GAP Results

\begin{tabular}{|c|c|c|c|c|}
\hline Dimension & Item Code & Performance Mean & Importance Mean & GAP \\
\hline \multirow[t]{8}{*}{ Usability } & U1 & 4.000 & 4.396 & -0.396 \\
\hline & $\mathrm{U} 2$ & 3.881 & 4.390 & -0.509 \\
\hline & U3 & 3.836 & 4.346 & -0.510 \\
\hline & $\mathrm{U} 4$ & 3.950 & 4.503 & -0.553 \\
\hline & U5 & 3.748 & 4.377 & -0.629 \\
\hline & U6 & 3.792 & 4.270 & -0.478 \\
\hline & $\mathrm{U} 7$ & 3.862 & 4.333 & -0.471 \\
\hline & U8 & 4.013 & 4.459 & -0.446 \\
\hline \multirow{7}{*}{$\begin{array}{l}\text { Information } \\
\text { Quality }\end{array}$} & IQ1 & 3.893 & 4.352 & -0.459 \\
\hline & IQ2 & 3.855 & 4.314 & -0.459 \\
\hline & IQ3 & 3.824 & 4.289 & -0.465 \\
\hline & IQ4 & 3.862 & 4.270 & -0.408 \\
\hline & IQ5 & 3.893 & 4.396 & -0.503 \\
\hline & IQ6 & 3.755 & 4.245 & -0.490 \\
\hline & IQ7 & 3.755 & 4.327 & -0.572 \\
\hline \multirow{7}{*}{$\begin{array}{l}\text { Service } \\
\text { Interaction }\end{array}$} & SI1 & 3.742 & 4.371 & -0.629 \\
\hline & SI2 & 3.843 & 4.289 & -0.446 \\
\hline & SI3 & 3.723 & 4.377 & -0.654 \\
\hline & SI4 & 3.830 & 4.333 & -0.503 \\
\hline & SI5 & 3.736 & 4.195 & -0.459 \\
\hline & SI6 & 3.811 & 4.289 & -0.478 \\
\hline & SI7 & 3.723 & 4.258 & -0.535 \\
\hline Overall view & $\mathrm{O} 1$ & 3.918 & 4.371 & -0.453 \\
\hline
\end{tabular}




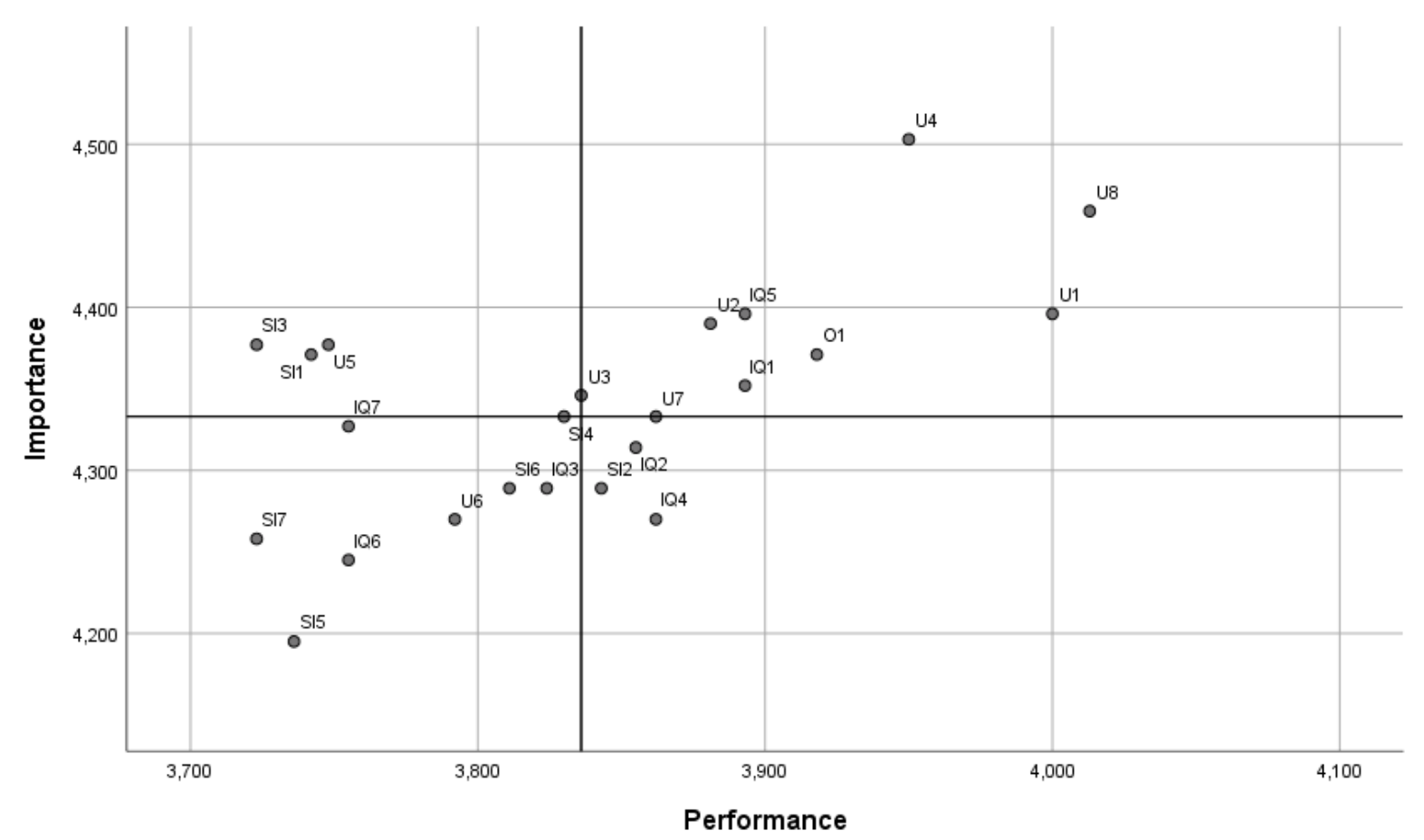

Figure 7. Cartesian Diagram of IPA for LAPOR

\section{Data Analysis for Webqual and Kano}

After data collection process throughout the questionnaire using Webqual method for dimension and attribute, the following process is the data analysis using Kano model. It consists of analysis of twoway quality model, and analysis of Kano quality Improvement Index.

1. Analysis of Two-Way Quality Model

The result of the questionnaire obtained for functional and dysfunctional for each respondent is paired based on the Table 5 below. The result can be classified into six categories: A (Attractive), M (Must-be quality), O (One-dimensional quality), I (Indifferent quality), R (Reverse quality) and Q (Questionable quality). Table 6 is the result of the classification process based on the Kano evaluation table.

Table 5. Kano Evaluation Table

\begin{tabular}{|c|c|c|c|c|c|c|}
\hline \multicolumn{7}{|c|}{ Dysfunctional } \\
\hline & & Like & Must-be & Neutral & Live With & Dislike \\
\hline \multirow{5}{*}{$\begin{array}{l}\text { Functio } \\
\text { nal }\end{array}$} & Like & $\mathrm{Q}$ & $\mathrm{A}$ & $\mathrm{A}$ & A & $\mathrm{O}$ \\
\hline & Must-be & $\mathrm{R}$ & I & I & I & M \\
\hline & Neutral & $\mathrm{R}$ & I & I & I & M \\
\hline & Live With & $\mathrm{R}$ & I & I & I & $\mathrm{M}$ \\
\hline & Dislike & $\mathrm{R}$ & $\mathrm{R}$ & $\mathrm{R}$ & $\mathrm{R}$ & Q \\
\hline
\end{tabular}


Table 6. Kano Category Result

\begin{tabular}{|c|c|c|c|c|c|c|c|c|c|}
\hline \multirow{2}{*}{ Dimensions } & \multirow{2}{*}{$\begin{array}{l}\text { Item } \\
\text { Code }\end{array}$} & \multicolumn{8}{|c|}{ Classification } \\
\hline & & $\mathbf{A}$ & $\mathbf{M}$ & $\mathbf{O}$ & I & $\mathbf{R}$ & $\mathbf{Q}$ & Total & Category \\
\hline \multirow[t]{8}{*}{ Usability } & U1 & 44 & 37 & 33 & 38 & 3 & 4 & 159 & $\mathrm{~A}$ \\
\hline & $\mathrm{U} 2$ & 42 & 36 & 37 & 38 & 3 & 3 & 159 & $\mathrm{~A}$ \\
\hline & U3 & 45 & 41 & 28 & 36 & 4 & 5 & 159 & $\mathrm{~A}$ \\
\hline & U4 & 37 & 38 & 46 & 30 & 2 & 6 & 159 & $\mathrm{O}$ \\
\hline & U5 & 44 & 23 & 39 & 41 & 7 & 5 & 159 & $\mathrm{~A}$ \\
\hline & U6 & 43 & 30 & 29 & 49 & 5 & 3 & 159 & I \\
\hline & U7 & 32 & 38 & 37 & 46 & 2 & 4 & 159 & I \\
\hline & U8 & 35 & 51 & 41 & 26 & 1 & 5 & 159 & $\mathrm{M}$ \\
\hline \multirow{7}{*}{$\begin{array}{l}\text { Information } \\
\text { Quality }\end{array}$} & IQ1 & 31 & 57 & 37 & 28 & 1 & 5 & 159 & $\mathrm{M}$ \\
\hline & IQ2 & 30 & 61 & 35 & 26 & 3 & 4 & 159 & $\mathrm{M}$ \\
\hline & IQ3 & 27 & 50 & 39 & 32 & 5 & 6 & 159 & $\mathrm{M}$ \\
\hline & IQ4 & 33 & 43 & 36 & 38 & 4 & 5 & 159 & $\mathrm{M}$ \\
\hline & IQ5 & 44 & 39 & 36 & 32 & 3 & 5 & 159 & $\mathrm{~A}$ \\
\hline & IQ6 & 34 & 48 & 32 & 37 & 4 & 4 & 159 & $\mathrm{M}$ \\
\hline & IQ7 & 36 & 34 & 34 & 51 & 1 & 3 & 159 & I \\
\hline \multirow{7}{*}{$\begin{array}{l}\text { Service } \\
\text { Interaction }\end{array}$} & SI1 & 30 & 38 & 49 & 35 & 3 & 4 & 159 & $\mathrm{O}$ \\
\hline & SI2 & 31 & 38 & 43 & 38 & 5 & 4 & 159 & $\mathrm{O}$ \\
\hline & SI3 & 31 & 39 & 45 & 35 & 3 & 6 & 159 & $\mathrm{O}$ \\
\hline & SI4 & 40 & 29 & 37 & 45 & 4 & 4 & 159 & I \\
\hline & SI5 & 36 & 28 & 37 & 49 & 5 & 4 & 159 & $\mathrm{I}$ \\
\hline & SI6 & 27 & 36 & 50 & 36 & 6 & 4 & 159 & $\mathrm{O}$ \\
\hline & SI7 & 28 & 44 & 47 & 36 & 1 & 3 & 159 & $\mathrm{O}$ \\
\hline Overall View & O1 & 36 & 51 & 41 & 26 & 1 & 4 & 159 & $\mathrm{M}$ \\
\hline
\end{tabular}

2. Analysis of Kano Quality Improvement Index

The score of each category for all 23-attributes in Table 6 is used to calculate the index of customer's satisfaction (SI) and index of customer's dissatisfaction (DI) (Equation 3 \& Equation 4).

Customer's Satisfaction $(\mathrm{SI})=\mathrm{A}+\mathrm{O} /(\mathrm{A}+\mathrm{O}+\mathrm{M}+\mathrm{I})$

Equation (3)

Customer's Dissatisfaction $(D I)=-(\mathrm{O}+\mathrm{M}) /(\mathrm{A}+\mathrm{O}+\mathrm{M}+\mathrm{I})$

Equation (4)

The calculation of both Index for each attributes is shown in Table 7.

The index of customer's satisfaction (SI) ranges from zero to one. The nearer the value is to one, the greater the impact of the meeting of the requirement on customer satisfaction, but the closer the value is to zero, lesser the influence. Table 7 shows that the top 5 improving satisfaction of LAPOR are the site easy to use (U4), attractive appearance (U5), easy to understand information (IQ5), good reputation (SI1), and communicate with the organization who handle the complaint (SI6). These attributes have great effects on increasing user satisfaction and reducing dissatisfaction and are highly concerned by users. LAPOR had better take these 5 attributes as top priority in enhancing their website quality. 
Table 7. Kano Quality Improvement Index

\begin{tabular}{|c|c|c|c|}
\hline Dimensions & $\begin{array}{l}\text { Item } \\
\text { Code }\end{array}$ & $\begin{array}{c}\text { Improving } \\
\text { satisfaction index }\end{array}$ & $\begin{array}{c}\text { Reducing } \\
\text { dissatisfaction index }\end{array}$ \\
\hline \multirow[t]{8}{*}{ Usability } & U1 & 0.507 & -0.461 \\
\hline & $\mathrm{U} 2$ & 0.516 & -0.477 \\
\hline & U3 & 0.487 & -0.460 \\
\hline & $\mathrm{U} 4$ & 0.550 & -0.556 \\
\hline & U5 & 0.565 & -0.422 \\
\hline & U6 & 0.477 & -0.391 \\
\hline & $\mathrm{U} 7$ & 0.451 & -0.490 \\
\hline & U8 & 0.497 & -0.601 \\
\hline \multirow{7}{*}{$\begin{array}{l}\text { Information } \\
\text { Quality }\end{array}$} & IQ1 & 0.444 & -0.614 \\
\hline & IQ2 & 0.428 & -0.632 \\
\hline & IQ3 & 0.446 & -0.601 \\
\hline & IQ4 & 0.460 & -0.527 \\
\hline & IQ5 & 0.530 & -0.497 \\
\hline & IQ6 & 0.437 & -0.530 \\
\hline & IQ7 & 0.452 & -0.439 \\
\hline \multirow{7}{*}{$\begin{array}{l}\text { Service } \\
\text { Interaction }\end{array}$} & SI1 & 0.520 & -0.572 \\
\hline & SI2 & 0.493 & -0.540 \\
\hline & SI3 & 0.507 & -0.560 \\
\hline & SI4 & 0.510 & -0.437 \\
\hline & SI5 & 0.487 & -0.433 \\
\hline & SI6 & 0.517 & -0.577 \\
\hline & SI7 & 0.484 & -0.587 \\
\hline Overall View & $\mathrm{O} 1$ & 0.500 & -0.597 \\
\hline
\end{tabular}

However, one must also take the index of customer dissatisfaction into consideration. If it approaches value minus 1 , the influence on customer dissatisfaction is especially strong if the product feature is not fulfilled. A value of about 0 signifies that this feature does not cause dissatisfaction if it is not met. The attributes of creates positive experience (U8), provides accurate information (IQ1), provides believable information (IQ2), provides timely information (IQ3), and overall view of the web site (O1) are ranked first 5 in influencing customer dissatisfaction in LAPOR. If these attributes are insufficient, users may feel strong dissatisfaction and it may arise the decrease in satisfaction when they are not fully fulfilled. LAPOR had better take these 5 attributes as top priority to decrease dissatisfaction.

\section{Discussion}

Since IPA and Kano model has the similar purpose, which is to analyzing customer satisfaction, the result of both data analysis process can be related to one another. The similar result intends to support each other's result, while the different result can be considered to enhance the result for more completeness and richness.

From the quadrant IPA analysis, the important quadrant for supporting customer satisfaction is quadrant 1 and quadrant 2 . The quadrant 1 is referred to the attributes needs to be the priority for 
improvement in LAPOR, while the quadrant 2 defines which attributes of LAPOR that need to keep up the good work of the quality.

While from the Kano model analysis, the index of customer's satisfaction (SI) referred to the attributes of LAPOR that have great effects on increasing user satisfaction which are highly concerned by users, while the index of customer dissatisfaction (DI) defines the attributes of LAPOR that make users may feel strong dissatisfaction when it is not fully fulfilled.

The results of both data analyzing process are similar even though it is not fully the same. So that the elaborate of the result is considered to summarize the attribute of LAPOR that needs to be focused on to enhance the system quality which leads to customer satisfaction. The attributes are easy to learn to operate (U1), interaction is clear and understandable (U2), the site easy to navigate (U3), the site easy to use (U4), attractive appearance (U5), creates positive experience (U8), provides accurate information (IQ1), provides believable information (IQ2), provides timely information (IQ3), easy to understand information (IQ5), good reputation (SI1), personal information feels secure (SI3), communicate with the organization who handle the complaint (SI6), and overall view of the web site (O1).

\section{Conclusion}

This research analyzes the requirement of the system quality that affect the customer satisfaction of LAPOR, as the online service for complaints provided by the government, using a Webqual 4.0 method. The measurement variables are usability, information quality, service interaction, and overall view. This research integrates Webqual method to Importance Performance Analysis (IPA) and Kano model as the data analysis process. Based on the GAP analysis of IPA shows that LAPOR has not fully meet the user's expectation of their system quality. The quadrant IPA analysis defines which attributes that needed to be focus for improvement which leads to customer satisfaction, while the analysis of Kano quality improvement index defines the attributes that affect user satisfaction and dissatisfaction. The integration of both data analysis process shows that there are 14-attributes out of 23 that need to be the priority for LAPOR improvements.

\section{References}

Al-Hujran, O., Al-Debei, M. M., Chatfield, A., \& Migdadi, M. 2015. "The imperative of influencing citizen attitude toward e-government adoption and use", Computers in Human Behavior (53:1), pp. 189-203.

Al-Nidawi, W. J. A., Al-Wassiti, S. K. J., Maan, M. A., \& Othman, M. 2018. "A review in Egovernment service quality measurement", Indonesian Journal of Electrical Engineering and Computer Science (10:3), pp. 1257-1265.

Andry, J. F., Christanto, K., \& Wilujeng, F. R. 2019. "Using Webqual 4.0 and Importance Performance Analysis to Evaluate E-Commerce Website", Journal of Information Systems Engineering and Business Intelligence (5:1), pp. 23-31.

Arnes, F., \& Hanum, Y. 2019. "Website Quality Evaluation of Visitor Satisfaction (Case Study: SBMPTN website)", International Research Journal of Advanced Engineering and Science (4:3), pp. 241-245.

Barnes, S.J., \& Vidgin, R.T. 2002. "Assessing The Quality of Auction Web Sites". Proceedings of the Hawaii International Conference on System Sciences, Maui, HI.

Dou, R., Zhang, Y., \& Nan, G. (2016). "Application of combined Kano model and interactive genetic algorithm for product customization", Journal of Intelligent Manufacturing" (30:1), pp. 25872602.

Joseph, S. R. 2015. "Advantages and disadvantages of E-government implementation: literature review", International Journal of Marketing and Technology (5:9), pp. 18-34.

LAPOR. 2020. “Apa itu LAPOR!?.” (https://www.lapor.go.id/tentang\#, accessed July, 2020)

Madzík, P., Budaj, P., Mikuláš, D., \& Zimon, D. 2019. "Application of the Kano Model for a Better Understanding of Customer Requirements in Higher Education-A Pilot Study", Administrative Sciences, (9:1), pp. 1-18. 
Martilla, J. A., \& James, J. C. 1977. "Importance-performance analysis”, Journal of Marketing (10:1), pp. 13-22.

Materla, T., Cudney, E., \& Hopen, D. 2019, "Evaluating factors affecting patient satisfaction using the Kano model", International Journal of Health Care Quality Assurance (32:1), pp. 137-151.

Padlee, S. F., Reimers, V., Mokhlis, S., Anuar, M. M., \& Ahmad, A. 2019. Keep up the good work in research universities: An importance-performance analysis", Australasian Marketing Journal $(A M J)(28: 2)$, pp. 128-138.

Phadermrod, B., Crowder, R. M., \& Wills, G. B. 2016. "Importance-Performance Analysis based SWOT analysis", International Journal of Information Management (2017) (44:1), pp. 194-203.

Sabani, A., Deng, H., \& Thai, V. 2018. "A Conceptual Framework for the Adoption of E-Government in Indonesia", 29th Australasian Conference on Information Systems (ACIS), 2018, Sydney, Australia, pp. 1-12.

Shahin, A., Pourhamidi, M., Antony, J., \& Park, S. H. 2013. "Typology of Kano models: A critical review of literature and proposition of a revised model", International Journal of Quality \& Reliability Management (30:1), pp. 341-58.

Widowati, D. P.W. 2018. "Survei PBB 2018: Peringkat E-Government Indonesia". (https://bpptik.kominfo.go.id/2018/08/23/5938/survei-pbb-2018-peringkat-e-governmentindonesia/, accessed July, 2020).

\section{How to cite:}

Rindani, F., and Puspitodjati, S. 2020. "Integration of Webqual Method to Importance Performance Analysis and Kano Model to Analyze System Quality of E-Government: Case Study LAPOR!," Jurnal Sistem Informasi (Journal of Information System) (16:2), pp. 1-17. 